\title{
Emergence of multidrug-resistant bacteria isolated from surgical site infection in dogs and cats
}

[Emergência de bactérias multirresistentes isoladas da infecção no sítio cirúrgico em cães e gatos]

C.M.M. Corsini, V.O. Silva, O.V. Carvalho, R.V. Sepúlveda, F.L. Valente, E.C.C. Reis, M.A.S. Moreira, A. Silva Júnior, A.P.B. Borges*

Universidade Federal de Viçosa - Viçosa, MG

\begin{abstract}
Surgical site infections (SSIs) and antimicrobial resistance among pathogens causing SSI are a growing concern in veterinary hospitals. One major reason, the widespread use of antimicrobials, has led to increased incidence of SSIs. This study identified bacteria and resistance profiles to antimicrobials in the SSI cases diagnosed at the Surgical Clinic of Small Animals in the Veterinary Hospital, Federal University of Viçosa, Brazil. The main genus identified was Staphylococcus, followed by Escherichia, Enterococcus, Bacillus, Shigella, Citrobacter, Proteus, Morganella, Serratia, Enterobacter, Pseudomonas and Klebsiella were also found, but in small number. The results indicated the predominance of Gram-negative bacteria among the collected samples. Most of isolates identified were resistant to more than one of the following antimicrobials: ampicillin, tetracycline, enrofloxacin, amoxicillin/clavulanic acid and cephalotin. Of the 17 Staphylococcus sp. isolates, two (11.8\%) were methicillin-resistant Staphylococcus aureus (MRSA) and 11 (64.7\%) of them were methicillin-resistant Staphylococcus pseudintermedius (MRSP). There were bacterial genera identified with resistance to all tested antimicrobials in different proportions. This should alert veterinary hospitals to the emergence of multidrug-resistant bacteria and to the requirement for the revision of surgical protocols with regard to antimicrobial prophylaxis and therapy.
\end{abstract}

Keywords: nosocomial infection, minimal inhibitory concentration, resistant pathogens

\section{RESUMO}

As infecções em sítio cirúrgico (ISCS) e a resistência bacteriana entre os patógenos relacionados constituem uma preocupação crescente nos hospitais veterinários. O aumento na incidência de ISCs possui forte relação com o uso amplo e disseminado de antibióticos. O presente estudo identificou bactérias e perfis de resistência a antibióticos nos casos de ISCs diagnosticados na Clínica Cirúrgica de Pequenos Animais do Hospital Veterinário da Universidade Federal de Viçosa, Brasil. O principal gênero identificado foi Staphylococcus, seguido pelos gêneros Escherichia, Enterococcus, Bacillus, Shigella, Citrobacter, Proteus, Morganella, Serratia, Enterobacter, Pseudomonas e Klebsiella, porém, em menor quantidade. Os resultados demonstraram a predominância de bactérias Gram-negativas entre as amostras coletadas. A maioria dos isolados identificados eram resistentes a um ou a mais de um dos seguintes antibióticos: ampicilina, tetraciclina, enrofloxacina, amoxicilina/ácido clavulânico $e$ cefalotina. Entre os 17 isolados de Staphylococcus sp., dois $(11,8 \%)$ eram Staphylococcus aureus resistentes à meticilina (SARM) e $11(64,7 \%)$ eram Staphylococcus pseudintermedius resistentes à meticilina (SPRM). Houve identificação de gêneros bacterianos com diferentes proporções de resistência para todos os antibióticos avaliados. Esses achados devem alertar os hospitais veterinários para a emergência de bactérias multirresistentes e para a necessidade de revisar a profilaxia e a terapia antimicrobiana referente aos protocolos cirúrgicos.

Palavras-chave: infecção nosocomial, concentração mínima inibitória, patógenos resistentes

Recebido em 22 de agosto de 2018

Aceito em 10 de dezembro de 2019

*Autor de correspondência (corresponding author)

E-mail: andrea@ufv.br 


\section{INTRODUCTION}

The surgical site infection (SSI) is a common and widespread nosocomial infection in human medicine (Humphreys, 2009) and is considered the most important cause of postoperative complications, contributing significantly to increased morbidity and mortality in these patients (Sitio..., 2009). In the past two decades, this type of infection has become an increasing concern in veterinary hospitals (Braga et al., 2012, Corsini et al., 2014, Murta et al., 2015).

SSI is the most frequently reported type of nosocomial infection in small animals, occurring in between $0.8 \%$ to $18.1 \%$ of all surgical wounds in dogs and cats (Nelson, 2011). Corsini et al. (2014) working in a veterinary hospital found an SSI infection rate of $5.24 \%$ and Murta et al. (2015) of $3.46 \%$. Most are caused by multiple microorganisms, usually multidrug-resistant (MDR), and have many risk factors (Braga et al., 2012).

There is an increasing concern about the antibiotic resistance, which has several implications for human or animal health like higher costs, extended stay in the hospital, delayed recovery and patient death. Importantly, resistant bacteria can appear quickly after the application of antibiotics, but the process to eliminate them is slow, even in the absence of selective pressure. Incrementing resistance is a usual feature of microorganisms causing nosocomial infections, which present a wide variety of mechanisms for resistance (Nelson, 2011).

MDR pathogens have been reported in veterinary hospitals and are more common in animals that have undergone prior treatment with antimicrobials (Pellerin et al., 1998). Gibson et al. (2008) described 37 dogs with MDR E. coli and Enterobacter extraintestinal infection. Almost $90 \%$ received prior antimicrobial therapy and about $60 \%$ had a surgical procedure. A recent study presented 194 isolates from canine SSIs and multidrug resistance was uncommon, despite the fact that MDR microorganisms have been increasingly reported (Windahl et al., 2015).

Methicillin-resistant Staphylococcus aureus (MRSA) and methicillin-resistant Staphylococcus pseudintermedius (MRSP) in animals have been highlighted in recent years (Wieler et al. 2011). According to Kottler et al. (2010) methicillinresistant strains, also called oxacillin-resistant, are resistant to all beta-lactam antibiotics, and are usually resistant to a variety of other classes of antibiotics as well. Although MRSA and MRSP share risk factors, particularly prior antibiotic use and hospitalization, they have probably emerged independently through adaptive process in their respective hosts (Huerta et al. 2011).

There are few published studies in veterinary medicine regarding the identification of nosocomial pathogens and assessment of control strategies for infection. Likewise, little information is available about the impact of multidrug and patterns of antimicrobial resistance related to isolated pathogens in small animals SSIs. Therefore, this study aimed to identify the bacteria causing SSI in dogs and cats and also evaluate antimicrobial resistance profiles of the isolates.

\section{MATERIALS AND METHODS}

The design of this study was approved by the Ethics Committee on Animal Use, Federal University of Viçosa (UFV-CEUA), under protocol number 60/2011.

The population used in this study was composed of dogs and cats submitted to surgery at HVTUFV from August 2, 2010 to July 1, 2011. Animals undergoing dental procedures were excluded from the study, because these procedures are performed in a different room as other medical procedures. The basic requirements for patient inclusion in the study were: being submitted to pre-surgical evaluation, medical records completed with clinical examination and anamnesis of the responsible professional, not being a carrier of infection at the time of admission and having attended the ambulatory surgical post-return.

The diagnosis of SSI was conducted during outpatient postsurgical return, which occurred between seven to ten days after the procedure. In return, the following criteria were used to evaluate the surgical wound: the presence of hyperemia, increased local temperature and or systemic pain, dehiscence and the presence of purulent exudate at the incision site. As the gold 
standard for diagnosis the presence of purulent exudate was assessed, which featured no reaction to the suture, according to the recommendations of the Centers for Disease Control and Prevention (CDC) through the Guideline for Prevention of Surgical Site Infection (Mangram et al., 1999).

The material used for microbiological analysis was collected through the edges, prior to cleaning of surgical wounds with a solution of polyvinylpyrrolidone (PVP), and $1 \%$ of the center thereof with $0.9 \%$ saline solution, to remove all of the purulent exudate present. The material to be analyzed was collected as deep as possible in the surgical wound with sterile swabs (Labor, Brazil). When the presence of scabs was observed, these were removed prior to cleaning the wound and sampling. Each swab containing different samples was inoculated with $1 \mathrm{ml}$ of $0.85 \% \mathrm{NaCl}$ and shaken vigorously. The contents of each were plated onto Petri dishes containing sheep blood agar $(5 \%$ HiMedia Laboratories, India) and incubated at $37^{\circ} \mathrm{C}$ for 24 hours. After that time, the colonies that showed visually distinct morphology were streaked onto BrainHeart-Infusion (BHI) agar (HiMedia Laboratories, India) to obtain pure cultures. Then, the cultures were stored in BHI broth supplemented with $20 \%$ glycerol and stored at $80^{\circ} \mathrm{C}$.

After the end of the harvest period, the stored isolates were reactivated in BHI agar to perform the following screening tests: Gram staining, and analysis of catalase and oxidase (Newprov, Brazil). Additionally, the isolated Gram-negative species underwent the following tests: IMViC, oxidation-fermentation of Hugh and Leifson (HiMedia Laboratories, India) and inoculated agar-Triple Sugar-Iron (TSI) (HiMedia Laboratories, India). Bacteria identified as Staphylococcus sp. were submitted to the free and bound coagulase tests. All of the above analyses were performed according to the protocols described by Koneman et al. (2008). For the quality control of the adopted culture media, we used the standard strains Escherichia coli ATCC 25922 and Staphylococcus aureus ATCC 12600.

After triage, the isolates passed through genotypic characterization by genome sequencing. The isolates were subjected to a genomic DNA extraction kit using the Wizard $\AA$ Genomic DNA Purification (Promega, USA). The coding region of the ribosomal $16 \mathrm{~S}$ sequence was amplified by conventional PCR using the primers and amplification cycles described by Sterr et al. (2009). PCR reactions were performed using the kit Go Taq® Green Master Mix (Promega, USA).

The amplified fragments of approximately 1,513 bp were visualized by electrophoresis on $1 \%$ agarose gel (Invitrogen, USA) colored with GelRed $^{\text {TM }}$ Nucleic Acid Stain (1X) using a UV light image capture system in L-PIX HE (Loccus Biotechnology, Brazil).

The amplicons were purified by the Wizard PCR clean up kit (Promega, USA) and sequenced. The obtained sequences were edited using software Sequencher ${ }^{T M}$ Version 4.1.4 and compared with other sequences available in GenBank using the software Basic Local Alignment Search Tool (BLAST), which is available from the National Center for Biotechnology Information - NCBI (http://www.ncbi.nlm.nih.gov). The nucleotide sequences determined in this study have been deposited in GenBank [GenBank: JX482487 to JX482547]. Phylogenetic tree based on the 16S RNA nucleotide sequences was reconstructed using the neighbor-joining method with 10,000 replicates using MEGA program.

For the antimicrobial susceptibility test, the minimum inhibitory concentration (MIC) was determined by the Etest antimicrobial gradient strips (BioMerieux, France) according to the manufacturer's guidelines. For Gram-positive bacteria, the following antimicrobials were tested: amoxicillin/clavulanic acid, ampicillin, cephalothin, oxacillin and tetracycline, the following were assessed for Gram-negative bacteria: amoxicillin/clavulanic acid, ampicillin, tetracycline, and enrofloxacin. Staphylococci were tested for susceptibility to oxacillin as indicator for methicillin resistance. The antimicrobials were chosen based on the routine surgical use in the veterinary hospital. The quality control of the culture medium was the same as mentioned above for biochemical tests. The MIC reading was performed according to the manufacturer's guidelines. Subsequently, the samples were classified as sensitive, intermediate or resistant in accordance with the sensitivity limits determined by the Standards Clinical 
Laboratory Institute, CLSI (Performance..., 2008).

\section{RESULTS AND DISCUSSION}

In total, 401 animals (354 dogs and 47 cats) had a surgical intervention during the study period. Twenty-one animals (18 dogs and three cats) were diagnosed with SSI, for an overall rate of $5.24 \%$. SSI rate at $5.24 \%$ identified in this study is similar to previous studies (Frey et al., 2010, Corsini et al., 2014), Already Murta et al. (2015) found an SSI rate of $3.46 \%$. However, different surgery types are usually related to variations in SSI rates. Turk et al. (2015) reported an infection rate of $20 \%$ for dirty procedures and only $3.2 \%$ for clean surgical interventions. Overall, SSI rates of $0.8 \%$ to $18.1 \%$ have been described in small animal surgeries (Nelson, 2011).

From these animals, 61 strains were obtained among dogs and cats, with no standard number of isolates per sample. We identified 12 bacterial genera among them, with $63.93 \%$ characterized as Gram-negative and $36.07 \%$ as Gram-positive
(Table 1 and Figure 1). Among the Staphylococcus samples, $80 \%$ were coagulasenegative and $20 \%$ coagulase-positive. Johnson and Murtaugh (1997) stated that the most common pathogens responsible for causing SSI in small animals are Staphylococcus aureus, Staphylococcus spp., E. coli and Pasteurella spp., most of them were identified in this work, except the genus Pasteurella (Table 1).

This study found $63.9 \%$ of species to be Gramnegative, confirming the previous results of Abdel-Fattah (2005), who conducted a study in a human hospital in relation to the identification of pathogens causing nosocomial infections, and found a higher rate of Gram-negative species. Also, in this work, the predominant genera were Escherichia and Staphylococcus, but this author did not stratify samples in his study, he simply related bacteria to SSI. However, our results agree with those found by Johnson and Murtaugh (1997) and suggest similarities between the bacteria found in the SSI of small animals and humans.

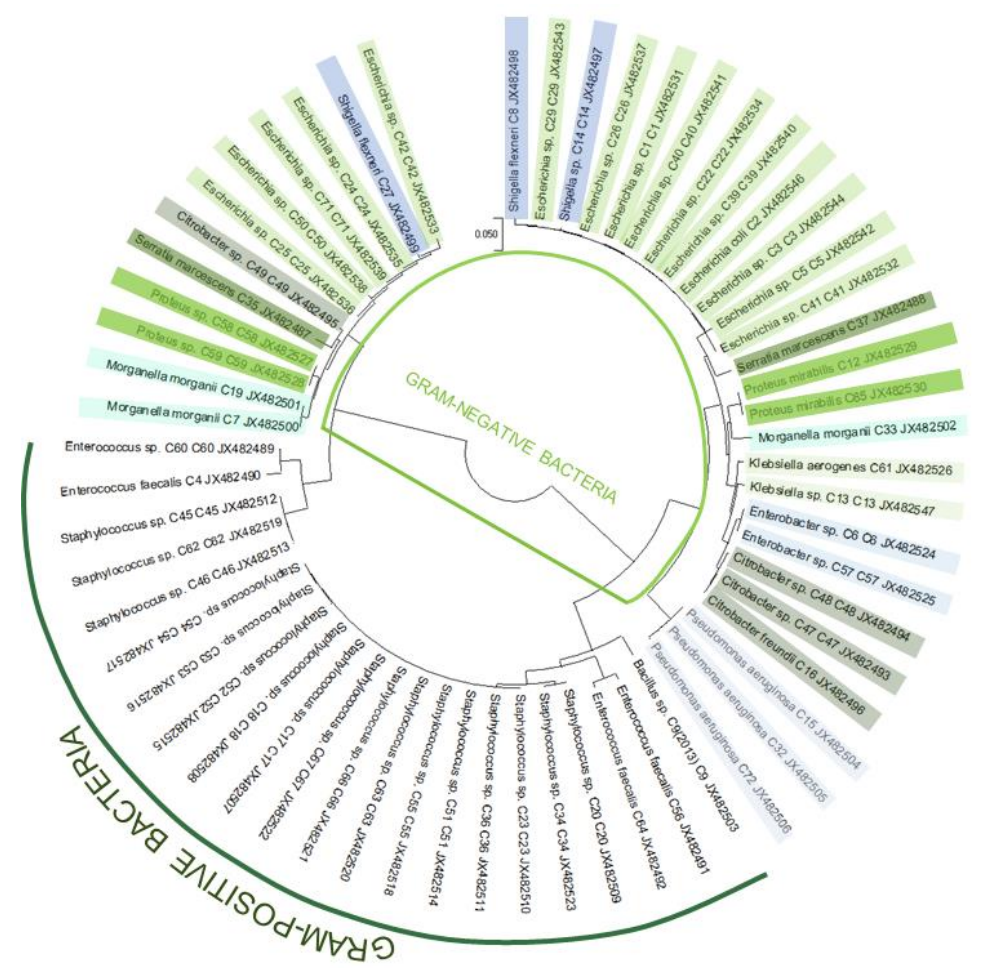

Figure 1. Phylogenetic clustering of 16S RNA partial sequence from bacteria of surgical site infections. Figure shows 61 bacteria isolates organized into gram-positive and gram-negative groups. 
Table 1. Bacteria isolated from surgical site infections in small animal surgery Bacterial strain

\begin{tabular}{|c|c|c|c|}
\hline & $\mathrm{n}(\%)$ & & Access Number Genbank \\
\hline Gram-negative & $\begin{array}{l}\text { Escherichia } \\
\text { fergusonii }\end{array}$ & $14(23.0)$ & JX482531-JX482544 \\
\hline Escherichia coli & $2(3.3)$ & & JX482545, JX482546 \\
\hline Shigella flexneri & $3(4.9)$ & & JX482497, JX482498, JX482499 \\
\hline Citrobacter freundii & $3(4.9)$ & & JX482493, JX482494, JX482496 \\
\hline Citrobacter murliniae & $1(1.6)$ & & JX482495 \\
\hline Proteus mirabilis & $3(4.9)$ & & JX482527, JX482529, JX482530 \\
\hline Proteus vulgaris & $1(1.6)$ & & JX482528 \\
\hline Morganella morganii & $3(4.9)$ & & JX482500, JX482501, JX482502 \\
\hline Serratia marcescens & $2(3.3)$ & & JX482487, JX482488 \\
\hline Enterobacter ludwigii & $2(3.3)$ & & JX482523, JX482524 \\
\hline Enterobacter carcerogenus & $1(1.6)$ & & JX482526 \\
\hline Klebsiella pneumoniae & $1(1.6)$ & & JX482547 \\
\hline Pseudomonas aeruginosa & $3(4.9)$ & & JX482504, JX482505, JX482506 \\
\hline Total & & $39(64.0)$ & \\
\hline Gram-positive & $\begin{array}{l}\text { Staphylococcus } \\
\text { pseudintermedius }\end{array}$ & $14(23.0)$ & $\begin{array}{l}\text { JX482507, JX482508, JX482511, } \\
\text { JX482512, JX482513, JX482515- } \\
\text { JX482522 }\end{array}$ \\
\hline Staphylococcus aureus & $2(3.3)$ & & JX482509, JX482523 \\
\hline Staphylococcus intermedius & $1(1.6)$ & & JX482514 \\
\hline Enterococcus faecalis & $3(4.9)$ & & JX482490, JX482491, JX482492 \\
\hline Enterococcus italicus & $1(1.6)$ & & JX482489 \\
\hline Bacillus thuringiensis & $1(1.6)$ & & JX482503 \\
\hline Total & & $22(36.0)$ & \\
\hline
\end{tabular}

Orthopedic surgery showed high SSI rate $(8.65 \%)$ compared to other surgeries. General, integumentary system, genitourinary, head and neck surgery showed SSI rate of $5.4 \%, 5 \%$, $2.82 \%$ and $2.77 \%$, respectively (Table 2 ). The two main genera present in SSI samples were Escherichia and Staphylococcus, which showed similar distributions in all of the cited locations/regions assessed. The detection percentage of bacterial isolates ranged from $1.64 \%(1 / 61)$ to $8.2 \%(5 / 61)$ (Table 2). The exceptions occurred in surgery around the head and neck, where only the presence of the genus Staphylococcus was identified, and in general surgery, with the same results for the genus Escherichia. Staphylococcus sp. and Escherichia sp. were detected in $33(54.1 \%)$ of the positive cultures. However, Staphylococcus sp. was the most frequently SSI pathogen isolated $(27.8 \%)$.

Most of bacterial species isolated in this study are usually found in the normal skin microbiota in healthy dogs and can be opportunistic pathogens in canine dermatitis and SSI. Some unusual bacteria isolates in small animals SSI might also be endogenous flora inoculation of surgical wounds or exogenous contaminants from environmental sources (Nelson, 2011).

The bacteria of the genera Pseudomonas, Klebsiella, Citrobacter, Enterobacter and Enterococcus identified in this study were also observed by Abdel-Fattah (2005) in human SSI. Van Eldere (2003) also noted the presence of Pseudomonas in human SSI, as well as other types of nosocomial infections. Boerlin et al. (2001) reported the presence of Enterococcus faecium and Enterococcus faecalis in SSI of dogs and cats. Also, in their papers, Abdel-Fattah (2005) observed the presence of the genera Proteus and Serratia in urinary tract infections in humans. There were no studies in veterinary medicine reporting the occurrence of the genus Morganella in SSI, which was another species identified in this study.

Staphylococci was the most prevalent infectious agent in our study and this finding was expected according to other studies, because $S$. pseudintermedius and $S$. aureus are opportunistic bacteria commonly related to SSI in animals (van Duijkeren et al., 2011). A recent study carried out by Windahl et al. (2015) have shown 
Staphylococcus pseudintermedius as the most common SSI finding identified and nearly twothirds of all isolates were staphylococci. Likewise, $S$. pseudintermedius was also the most prevalent pathogen according to another study (Turk et al., 2015).

Whittem et al. (1999) reported that bacteria of the genera Staphylococcus are usually the main cause of SSI in orthopedic procedures in small animals, as did Leonard et al. (2006), who suggested that the persistence of MRSA was the cause of most infections related to orthopedic devices. On the other hand, this was not observed in this work, since the main genera identified in orthopedic procedures with a positive diagnosis for SSI was Escherichia. Associations between deep wound infections and Escherichia coli isolates are more frequently observed than in superficial infections (Windahl et al., 2015).

Regarding antimicrobial resistance, the isolates showed high resistance to ampicillin. Among the Gram-positive species, tetracycline and cephalothin amoxicillin/clavulanic acid resistance was also observed, while the Gramnegative bacteria were resistant to tetracycline, enrofloxacin and amoxicillin/clavulanic acid, as outlined in Table 3. Out of the stored isolates identified as Staphylococcus sp., $76.47 \%$ showed resistance to oxacillin (see Table 3). Of the 17 Staphylococcus sp. isolates, two (11.8\%) were methicillin-resistant Staphylococcus aureus (MRSA) and 11 $(64.7 \%)$ of them were methicillin-resistant Staphylococcus pseudintermedius (MRSP) (Table 1 and Figure 1).

The observation of ampicillin resistance in both Gram-negative (51.28\%) and Gram-positive bacteria $(63.64 \%)$, suggests the improper use and/or abuse of this antimicrobial in routine surgery at the veterinary hospitals sampled, which may also be extrapolated to tetracycline and cephalothin. Nevertheless, this resistance can also be attributed to the widespread use of these antibiotics in other hospitals and veterinary clinics, and even outside the hospital.

The high rate of oxacillin resistance among isolates identified as Staphylococcus sp. in this work $(76.47 \%)$ was consistent with the data found in human studies conducted by Arias et al. (2003). Of these methicillin-resistant staphylococcal species, all Staphylococcus aureus isolated $(\mathrm{n}=2)$ in the present study were MRSA. A previous study reported $11 \%$ of MRSA isolates among $S$. aureus strains recovered from dogs in seven teaching hospitals in the United States (Middleton et al., 2005).

There has been an increasing number of MRSA infections in pets in recent years, indicating that most of these infections are associated with SSI and non-surgical wound infections (Cain, 2013). The increasingly closer contact between cats and dogs and humans may serve as a contributing factor in the increasing number of cases of MRSA infection in these animals, as well as the emergence of strains of $S$. aureus in the community, outside the hospital, called cMRSA, which are resistant to fewer antibiotics than MRSA, but is still resistant to methicillin (oxacillin) (Leonard et al.,2006).

Most of methicillin-resistant strains isolated in the present study were MRSP. Methicillinresistant $S$. pseudintermedius diagnosed in our study was also identified in other studies and this is of concern because MRSP had a notable increase in the prevalence of opportunistic infections in dogs and cats (Turk et al., 2015). Similar to the high rate of MRSP (11 of the 17 Staphylococcus isolates) observed in the present study, MRSP have been increasingly reported in Europe (Perreten et al., 2010). Unlike the MRSP incidence shown in this study and despite its expanding clinical impact, it was a rare finding in a recent study about SSI in dogs (Windahl et al., 2015).

According to Clarke (2006), antimicrobial resistance of bacteria affecting small animals varies considerably according to geographic location, history of exposure to antimicrobials, and the microorganisms involved, which could explain some variations found in this study. The small number of published studies in small animals SSIs may be the result of the absence of a database, which would be necessary for the development of an epidemiological study, as demonstrated by this work.

In Table 3 it can be observed that most bacteria identified in this study showed multidrug resistance, with isolates exhibiting resistance to more than one group of antimicrobials, reaching to a profile of resistance up to five 
antimicrobials, the exceptions being the genera Bacillus and Pseudomonas.

\section{CONCLUSIONS}

The diagnosed SSI in the Surgical Clinic of Small Animal Veterinary Hospital of UFV, Brazil, showed the presence of bacteria from 12 genera, most of which were Gram-negative. The predominant genus was Staphylococcus, followed by Escherichia. A high percentage of MRSP was reported, but also had two MRSA isolates. Isolated pathogens were mostly resistant to more than one antimicrobial. Due to the profile of multidrug-resistant bacteria isolated from SSIs, this study suggests the necessity of establishing a Service of Hospital Infection Control, which will follow the evolutions of postoperative infections and coordinate the correct use of antibiotics in veterinary medicine.

\section{ACKNOWLEDGEMENTS}

This work was supported CNPq, CAPES and FAPEMIG. The authors thank the Veterinary Department, Federal University of Viçosa (UFV). Abelardo Silva-Júnior, Maria Aparecida Scatamburlo Moreira and Andréa Pacheco Batista Borges were supported by CNPq.

\section{REFERENCES}

ABDEL-FATTAH, M.M. Surveillance of nosocomial infections at a Saudi Arabian military hospital for a one-year period. Ger. Med. Sci., v.3, p1-10, 2005.

ARIAS, C.A.; REYES, J.; ZÚÑIGA, M. et al. Multicentre surveillance of antimicrobial resistance in enterococci and staphylococci from Colombian hospitals, 2001-2002. J. Antimicrob. Chemother., v.51, p.59-68, 2003

BOERLIN, P.; EUGSTER, S.; GASCHEN, F. et al. Transmission of opportunistic pathogens in a veterinary teaching hospital. Vet. Microbiol., v.82, p.347-359, 2001.

BRAGA, D.P.; BORGES, A.P.B.; CARVALHO, T.B. et al. Antibioticoprofilaxia em cirurgias de cães e gatos: necessidade e realidade. Rev. Ceres, v.59, p.758-764, 2012.
CAIN, C.L. Antimicrobial resistance in staphylococci in small animals. Vet. Clin. N. Am. Small Anim. Pract., v.43, p.19-40, 2013.

CLARKE, C.R. Antimicrobial resistance. Vet. Clin. N. Am. Small Anim. Pract., v.36, p.9871001, 2006.

CORSINI, C.M.M.; BORGES, A.P.B.; ALBERTO, D.S.; SILVA, C.H.O. Incidência de infecção do sítio cirúrgico e fatores de risco associados na clínica cirúrgica de pequenos animais. Arq. Bras. Med. Vet. Zootec., v.66, p.737-744, 2014.

FREY, T.N.; HOELZLER, M.G.; SCAVELLI, T.D. et al. Risk factor for surgical site infectioninflammation in dogs undergoing surgery for rupture of the cranial cruciate ligament: 902 cases (2006-2006). J. Am. Vet. Med. Assoc., v.236, p.88-94, 2010.

GIBSON, J.S.; MORTON, J.M.; COBBOLD, R.N. et al. Multidrug-resistant E. coli and enterobacter extraintestinal infection in 37 dogs. J. Vet. Intern. Med., v.22, p.844-850, 2008.

HUERTA, B.; MALDONADO, A.; GINEL, P.J. et al. Risk factors associated with the antimicrobial resistance of staphylococci in canine pyoderma. Vet. Microbiol., v.150, p.302308, 2011.

HUMPHREYS, H. Preventing surgical site infection. Where now? J. Hosp. Infect., v.73, p.316-322, 2009.

JOHNSON, J.A.; MURTAUGH, R.J. Preventing and treating nosocomial infection. Part 2. Wound, blood and gastrointestinal infections. Comp. Cont. Educ. Pract., v.19, p.693-703, 1997.

KONEMAN, E.W.; ALLEN, J.; JANDA, W. et al. Diagnóstico microbiológico. 6.ed. Rio de Janeiro: Medsi, 2008. 1488p.

KOTTLER, S.; MIDDLETON, J.R.; PERRY, J. et al. Prevalence of Staphylococcus aureus and methicillin-resistant Staphylococcus aureus carriage in three populations. J. Vet. Intern. Med., v.24, p.132-139, 2010.

LEONARD, F.C.; ABBOTT, Y.; ROSSNEY, A. et al. Methicillin-resistant Staphylococcus aureus isolated from a veterinary surgeon and five dogs in one practice. Vet. Rec., v.158, p.155-159, 2006. 
MANGRAM, A.J.; HORAN, T.C.; PEARSON, M.L. et al. Guideline for prevention of surgical site infection, 1999. Infect. Control Hosp. Edemiol., v.20, p.250-278, 1999.

MIDDLETON, J.R.; FALES, W.H.; LUBY, C.D. et al. Surveillance of Staphylococcus aureus in veterinary teaching hospitals. J. Clin. Microbiol., v.43, p.2916-2919, 2005.

MURTA, A.R.; ABREU JR., N.B.; OLIVEIRA, L.S. et al. Perfil epidemiológico e análise microbiológica da infecção de sítio cirúrgico em pacientes humanos e animais de companhia. Pesqui. Vet. Bras., v.35, p.652-658, 2015.

NELSON, L.L. Surgical site infections in small animal surgery. Vet. Clin. N. Am. Small Anim. Pract., v.41, p.1041-1056, 2011.

PELLERIN, J.L.; BOURDEAU, P.; SEBBAG, H.; PERSON J.M. Epidemiosurveillance of antimicrobial compound resistance of Staphylococcus intermedium clinical isolates from canine pyodermas. Comp. Immunol. Microbiol. Infect. Dis., v.21, p.115-133, 1998.

PERFORMANCE standards for antimicrobial disk and dilution susceptibility tests for bacteria isolated from animals. Document M31-A3. Approved standard. 3.ed. Wayne, PA: Clinical and Laboratory Standards Institute, 2008. p.116.

PERRETEN, V.; KADLEC, K.; SCHWARZ, S. et al. Clonal spread of methicillin-resistant Staphylococcus pseudintermedius in Europe and North America: an international multicenter study. J. Antimicrob. Chemother., v.65, p.1145$1154,2010$.

SÍTIO cirúrgico: critérios nacionais de infecções relacionadas à assistência à saúde, 2009. Brasília: ANVISA, 2009. Disponível em: $<$ https://www.anvisa.gov.br/servicosaude/manuai s/criterios_nacionais_ISC.pdf $>$. Acessado em: 1 ago. 2018.
STERR, Y.; WEISS, A.; SCHMIDT H. Evaluation of lactic acid bacteria for sourdough fermentation of amaranth. Int. J. Food Microbiol., v.136, p.75-82, 2009.

TURK, R.; SINGH, A.; WEESE J.S. Prospective surgical site infection surveillance in dogs. Vet. Surg., v.44, p.2-8, 2015.

VAN DUIJKEREN, E.; CATRY, B.; GREKO, C. et al. Review on methicillin-resistant Staphylococcus pseudintermedius. J. Antimicrob. Chemother., v.66, p.2705-2714, 2011.

VAN ELDERE, J. Multicentre surveillance of Pseudomonas aeruginosa susceptibility patterns in nosocomial infections. J. Antimicrob. Chemother., v.51, p.347-352, 2003.

WHITTEM, T.L.; JOHNSON, A.L.; SMITH, C.W. et al. Effect of perioperative prophylactic antimicrobial treatment in dogs undergoing elective orthopedic surgery. J. Am. Vet. Med. Assoc., v.215, p.212-216, 1999.

WIELER, L.H.; EWERS, C.; GUENTHER, S. et al. Methicillin-resistant staphylococci (MRS) and extended-spectrum beta-lactamases (ESBL)producing Enterobacteriaceae in companion animals: nosocomial infections as one reason for the rising prevalence of these potential zoonotic pathogens in clinical samples. Int. J. Med. Microbiol., v.301, p.635-641, 2011.

WINDAHL, U.; BENGTSSON, B.; NYMAN, A.K.; HOLST B.S. The distribution of pathogens and their antimicrobial susceptibility patterns among canine surgical wounds infections in Sweden in relation to different risk factors. Acta Vet. Scand., v.57, p.11, 2015. 